https://doi.org/10.52240/1857-2367.2020.2(21).40

\title{
SOME ASPECTS OF THE STUDY ON THE SPECIES PHACELIA TANACETIFOLIA BENTH. AS HONEY PLANT IN THE REPUBLIC OF MOLDOVA
}

\author{
Natalia CÎRLIG \\ “Al. Ciubotaru” National Botanical Garden (Institute), \\ Chisinau, Republic of Moldova
}

\begin{abstract}
Phacelia tanacetifolia Benth., which is a species with high potential as forage and honey plant, served as the subject of a new study. The species is characterized by short growing season, staggered and long flowering period (about 55 days depending on the climatic conditions and the date when it was sown). Under laboratory conditions, the germination capacity of the seeds is $84-92 \%$. The climatic conditions of the Republic of Moldova allow P. tanacetifolia plants to complete the whole ontogenetic development cycle - they bloom, bear fruit and produce viable seeds.
\end{abstract}

Key words: Phacelia tanacetifolia Benth., honey plants, germination, development, flowers, seeds.

Phacelia tanacetifolia Benth. is an annual herbaceous plant with a wide range of uses that is part of the Hydrophyllaceae Lindl. family. It is known as a honey plant, with a production capacity of $200-300 \mathrm{~kg} / \mathrm{ha}$, providing food for pollinating insects during the period when other traditional species of honey plants are not in the flowering stage [3]. European beekeepers call it "bee bread", "friend of bees", "bee grass" [2]. The nectar of lacy phacelia has a rich content of organic substances, such as: sucrose (53.2\%), glucose $(14.7 \%)$ and fructose $(21.9 \%)$ [1].

The seeds and plants of P. tanacetifolia from the collection of the "Alexandru Ciubotaru" National Botanical Garden (Institute)(NBGI), the sector of forage and honey plants of the Plant Resources laboratory, were the subjects of study. The germination capacity of the seeds was determined under laboratory conditions. The weight of 1000 seeds and the number of seeds in a gram were calculated. Seeds were sown in different periods (beginning and end of March, beginning of May), in order to determine the biological characteristics of plants in different periods and climatic conditions of the spring-summer season 2020. During the growing season, we performed the phenological study and recorded the duration of the vegetative and generative stages of plants under the climatic conditions of the Republic of Moldova.

P. tanacetifolia is considered a valuable honey plant, and the research on the biological features of growth and development in the generative period allows highlighting the valuable features of plants and the subsequent recommendation of the species for the creation of plantations on large territories. In the literature, lacy phacelia has been described as a honey plant, the productivity of which can range between 600 and $1000 \mathrm{~kg} /$ ha, and the amount of nectar is $1.0-4.5 \mathrm{mg} /$ flower, with an average concentration of $28 \%$ sugar [4]. In NBGI, it was introduced as a potential forage crop, and is currently being researched as a honey plant that can produce large amounts of nectar. Under the given climatic conditions, during a growing season, lacy phacelia is able to complete the whole ontogenetic cycle of development: it blooms, bears fruit and produces viable seeds. The lacy phacelia seeds germinate well under laboratory conditions at temperatures between 
$+16 \mathrm{C}$ and $+22 \mathrm{C}$, and in open field, they begin to germinate at temperature from $+8^{\circ} \mathrm{C}$ to $+12^{\circ} \mathrm{C}$. The germination capacity of the seeds is $84-92 \%$. In the vegetative phases, the plants grow branched stems and a large number of leaves with a large photosynthetic surface. In the generative phases, the stems elongate significantly and the plants produce many inflorescences with small light blue flowers, attractive for different species of insects. The maintenance of a lacy phacelia plantation does not require many expenses, being necessary only the removal of the weeds in the first phase of vegetation.

Mature plants can grow about $115-120 \mathrm{~cm}$ tall. The main stem is pubescent, branched. Lateral branches of the first order, 50-65 cm long, with 4-6 leaves, are formed practically from each node. In later stages of development, second-order lateral branches are formed; they have usually 2-3 leaves and are much smaller in size than the leaves on the main shoot. In the end, a bushy plant with 15-22 branches is formed. The leaves are alternate, sessile and pinnate, with 7-8 toothed or pinnate leaflets. The basal leaves are larger, alternate, asymmetrical, pinnatisect, with an odd number of segments with irregular edges - from sharp to obtuse.

The blooming is staggered. On one plant, at the same time, there can be buds, flowers, and at the base of the inflorescences on the main shoot - fruits start developing. It blooms in April-June, depending on the sowing time. The flowering stage lasts about 55 days. Usually, 40-55 days pass from the emergence of seedlings until flowering. A plant produces about 15-20 inflorescences. The scorpiod inflorescences consist of 4-6 coiled cymes (curls), which straighten as the flowers wither and the fruits develop, taking shape of long spike-like cymes. On the main stem, the inflorescences are larger, with more curls and flowers. A curl usually consists of 18-22 flowers. The flowers are sessile, actinomorphic, with double perianth. The corolla is bell-shaped and consists of 5 blue-lilac petals. The calyx has sepals covered with hairs. The androecium consists of 5 free stamens with long filament, which protrude from the flower, and large anthers. During the growing season, lacy phacelia plants can form new, small inflorescences on the lateral branches, thus extending the period during which the bees can collect nectar. The fruit is a small dehiscent capsule with 4 black seeds. The weight of 1000 seeds are 1.9-2.0 g.

The research shows that $P$. tanacetifolia is an important source of food for pollinating insects and especially honey-producing ones. The long flowering period and the large number of inflorescences and flowers on the plants provide an important source of nectar for bees, but also a significant amount of biomass.

The research was supported by the NARD through the project "Mobilization of Plant Genetic Resources, Plant Breeding and as Forage, Melliferous and Energy Crop in Bioeconomy", 20.80009.5107.02

\section{BIBLIOGRAPHY}

1. Зауралов О. А. Растение и нектар. Саратов: Сарат. Ун-та, 1985, 180 с.

2. Клименкова Е., Кушнир Л., Бачило А. Медоносы и медосбор. Минск: Ураджай, 1980. 280 с.

3. Чибис С. и др. Сроки посева медоносной культуры фацелии пижмолистной (Phacelia tanacetifolia Benth.) в Омской области. - Омск: ОмГАУ им. П. А. Столыпина, 2017. - 169-174 с.

4. http://www.eurohonig.com/index.php?pagina=facelia 